\title{
5. DOCUMENTATION \\ (Committee of the Executive Committee)
}

PRESIDENT : J.-C. Pecker.

VICE-PRESIDENT : W.D. Heintz.

ORGANIZING COMMITTEE : D.A.Kemp, J.Kleczek, P.Lantos, J.R.Shakeshaft,

T.S.Shcherbina-Samojlova, G.A.Wilkins. ex officio : J.Sahade.

Les activités de la Commission se classent en trois rubriques principales, autour des trois groupes de travail.

I. EDITORIAL POLICY (Working Group; chairman: J.R. Shakeshaft).

1. Proliferation of journals.

A la requête de J.Sahade, Président du POGSI, les membres de la Commission 5 ont donné des avis sur ce problème. Quelques extraits significatifs des suggestions relatives aux solutions possibles :

- Instead of subscribing to all journals of interest to someone, one could periodically (every week) receive a listing and abstract of all astronomical papers published in that period (Dixon).

- One should suppress commercial journals; criticisms can be directed against the monopoly enjoyed by the IAU's publisher, and against the IAU policy in this matter (Griffin).

- But the multiplicity of journals is a safeguard to the freedom of actions of individuals (McNally).

-Peut-être serait-il suffisant de déposer les manuscrits dans un centre international approprié, et de ne publier qu'un résumé de 3 ou 4 pages; dans des revues de vaste profil, on ne publierait que les plus intéressants de ces résumés (Mikhaílov).

- There is almost an inverse correlation between the price charged ... and the standard of work : the IAU members should be more stringent in their refereeing procedures... and reduce the length of second-rate papers (Mitton).

2. Style of references in journals and publications.

The Commission should try to reach an agreement from all major journals on a uniform style of reference (Mitton, de Vaucouleurs). The Commission should also improve the IAU Style Book on this matter (Osterbrock).

3. Publication in microfiche.

This system is starting to spread (cf. Ap.J. and Memories of the RAS). One should discuss the possibility of microfiche publication of all major journals; and one should seriously consider the production of synopsis journals: it could make the problem of data storage and retrieval very much easier (McNally).

4. Tables published in journals.

A legible reproduction should always be ensured; lists of data are of a permanent value to astronomy and should be handled with special care (Worley).

II. ASTRONOMICAL DATA (Working Group; chairman: G.A.Wilkins).

1. The chairman of the $W G$ reports as follows : "The Working Group on Numerical Data was renamed the Working Group on Astronomical Data and was reconstituted with an organising committee and three subgroups at the IAU General Assembly in 1976. (Trans. IAU. 16B, 70-71). It is expected that these subgroups (on "Computer tech- 
nology and standards", "Designation of astronomical objects", and "Presentation of astronomical data") will report to the main group during 1979.

The proceedings of IAU Colloquium No.35 on the "Compilation, critical evaluation and distribution of stellar data", which was held at Strasbourg, France, on 1976 August 19-21, were published by Reidel in 1977 (ISBN 90-277-0792-8). This volume contains an extensive survey of astronomical data centres and services and a summary report on the papers and discussions, as well as the texts of four review papers and 33 other papers on current and future activities and problems. Although the main interest was centred on stellar data, the survey and much of the other material are relevant to other types of astronomical data.

The Information Bulletin of the Stellar Data Centre at Strasbourg continues to provide an extremely valuable source of information about astronomical data. Again, the contents cover a wider field than the title implies. The list of catalogues available at the Centre includes many entries for non-stellar objects. The Bulletin also includes lists of errata for published catalogues and short papers on work in progress at the participating observatories and elsewhere. The International Information Bureau on Astronomical Ephemerides at the Bureau des Longitudes in Paris has issued a further 21 cards giving information about star catalogues and ephemerides that are now available.

An interesting article by C.Jaschek on "Data growth in astronomy" (Q.JI.R. astr.Soc.,1978, 19, 269-276) concludes that : "Contrary to the common belief, the growth rates (of data in modern astronomy) vary from one subject to another, and there is generally no exponential growth. A sizable fraction of all newly published data ( 28 per cent) refers to objects already observed. This shows that a real "bibliographic inaccessibility" problem exists". If this latter conclusion can be justified, then it is clear that improved arrangements for the dissemination of evaluated data (or of information about their availability) could avoid the waste of resources that may be currently incurred by unnecessary duplication of observation, reduction and publication of astronomical data. This matter appears to deserve further consideration by the individual Commissions of the Union as well as by Commission 5 .

The data activities of other international organisations are of relevance to astronomy and the following points may be noticed.

The ICSU Committee on Data for Science and Technology (CODATA) has set up a Task Group on Space and Time Dependent Data, and it is hoped that this Group will identify ways in which advances in data-handling techniques made in one field can be made known and applied in other fields more quickly than has been common in the past. M.S. Davis represents the IAU on this Task Group. CODATA is also preparing for publication an updated and expanded version of Jaschek's survey of astronomical data centres and services as one section of its Directory of Data Sources for Science and Technology.

The Federation of Astronomical and Geophysical Services (FAGS) continued to allocate grants made by ICSU and UNESCO in support of the permanent data services of common interest to IAU, IUGG and URSI. One of the IAU delegates, H.Enslin, was appointed Chairman of the Council in 1977. The responsibility for the production of the Quarterly Bulletin on Solar Activity was transferred from Zurich to the Tokyo Astronomical Observatory; the Bulletin has been edited by Professor M.Waldmeier for the past 30 years; the new editor is Dr. F.Moriyama.

All IAU members who wish to take an active interest in the activities of the Working Group should make their interests known to the Chairman and should apply to become members of Commission 5; membership of Commission 5 may be additional to membership of three other Commissions."

2. The two following publications by NASA are also to be noted :

- Directory of Astronomical Data Files.

- HD-SAO-DM Cross Index.

(Two important publications; information can be obtained from J.Mead, Assistant Chief, Laboratory for Astronomy and Solar Physics, National Space Science Data Center, NASA/GSFC code 601.4, Greenbelt,Md 20771 USA, Attn. Request Coordina- 
tion, NASA TM 79564).

III. CLASSIFICATION DECIMALE UNIVERSELLE UDC 52 (groupe de travail; chairman : D.A. Kemp) ET SERVICES ANALYTIQUES ET SIGNALETIQUES.

1. L'édition du "Handbook on UDC 52" n'a encore pu être menée à bien, à la date de ce rapport (D.A. Kemp).

2. On signalera la publication (trilingue) par l'ICSU AB du plan international de classification de la physique, seconde édition, ISSN 0305-9618, 1978; la section 9 concerne la géophysique, l'astronomie et l'astrophysique. Cet ouvrage peut convenir aux physiciens; les astronomes préfèrent l'UDC 52 qui a été conçu différemment et utilise systématiquement le système des "facettes". L'UDC 52 contient de beaucoup plus nombreuses rubriques.

Une coopération plus étroite sur ces questions devrait se poursuivre avec I'ICSU AB (L.Schmadel).

3. L. Schmadel, responsable de la publication de Astronomy and Astrophysics Abstracts, rapporte comme suit : "Astronomy and Astrophysics Abstracts has continued to be published regularly in semi-annual volumes. Since the 1976 Grenoble meeting six volumes ( 17 to 22) have appeared covering the literature from 1976 to 1978. An Index Volume including a complete Author and Subject Index for the first ten volumes (period 1969 to 1973) has appeared as Nos. 15/16 in 1976. The preparation of our second Index Volume 23/24 (période 1974 to 1978) will be finished late in this year.

An effort has been made in order to increase drastically the size of our Subject Indexes. Astronomy and Astrophysics Abstracts aims to present a comprehensive list of astronomical terms as a first approximation of a thesaurus. This list of key words - or vocabulary- could serve as an aid for authors, editors, and publishers of primary journals. I hope that I will be able to complete a computer printing of a key word list, consisting of some 10,000 to 15,000 terms, until our Montreal meeting. This list will be a corrected and amended conglomerate of the first 21 volumes of AAA".

4. I. Schcherbina-Samojlova, responsable du département d'Astronomie et de Géodésie de VINITI, rapporte comme suit : " (i) VINITI Astronomy and Geodesy Department continued to publish Abstracts Journals (Referativnyi Zhurnal): 51. Astronomy, 62.Space Research and 52.Geodesy and Aerial Surveying. In 1977 the total number of abstracts amounted to 20000 in the three issues. (ii) Next volumes of state-of-theart reviews (so called Itogy Nauki) were issued : Serie Astronomy. 1976, 12, Parts 1,2. "Movement of Poles and Earth rotation irregularities". 1977, 13, "Radioastronomy". Serie Space Research. 1976, 8, "Optical systems and receivers of images of optical telescopes". 1977, 9, "Galaxy and extragalaxy astronomy (Astrophysics of high energies)". 1977, 10, "Planets of the Solar system. Mars". (iii) Preparation is begun for publication of Sovjet Astronomy Bibliography for 20 years (1958-1977) in four volumes. V.I,II publication is scheduled - 1980. Now preparation is underway for the Annotating Index of all scientific literature on the Moon and related investigations for 10 years (1968-1977). Printing is planned for 1979. (iv) The new revised UDC schedules 52 Astronomy were published in Russia. In 1978, the preparation of alphabetic-subject index for these tables will be completed. (v) In 1976-1977 the astronomical classification scheme was considerably improved as applied to the subject-heading list of the Abstracts Journals Astronomy and Space Research. (vi) The elaboration of astronomical terminological thesaurus is going on. (vii) Dr. I.S. Shcherbina-Samojlova carried out an analytical comparison of the Sovjet astronomy abstracts journal and Astronomy and Astrophysics Abstracts with view to optimizing of informational support of astronomers. A paper was written. (viii) The following papers were published : I.S.Shcherbina-Samojlova, T.I. Zapolskaya "System of Cross-Reference in the (astronomical) Abstracts Journal" (Bul. Nauchno-tehknicheskaya informatsiya, ser.1, 1978, N 3,24-28); V.T. Federov, 
"Ranking of Publications on a Fundamental scientific and technological problem (with reference to radioastronomy)" (Bul. Nauchno-techniceskaya informatsiya, ser. $1,1978, \mathrm{~N} 2,15) . "$

5. One should also note with interest the activity in the field of documentation of various organisations from which reports have been received :

-Primary Communications Research Centre (at the University of Leicester; Director : Prof. A.J. Meadows).

- International Association of Institutes of Navigation (IAIN). IAIN is preparing an "Annotated Bibliography of Methods and Tables for Astronomical Navigation" (project directed by Captain Charles H. Cotter, Dept. of Maritime Studies, UWIST, King Edward VII Avenue, Cardiff CF1 3NU).

6. On notera avec intérêt les ouvrages suivants :

- Seal, R., 1978, A guide to the literature of astronomy, Libraries unlimited.

- Walsh, J.R, 1977-78, Classification of Astronomy (submitted in partial fulfilment for the degree of M. Sc. (Inf. Sci.), University of Sheffield).

IV. DIVERS.

1. Archives d'observatoires.

M. J.0. Fleckenstein écrit : "Les archives des anciens observatoires (Paris, Greenwich, Milan, etc...) ont une valeur inestimable pour l'histoire des sciences. Pour cette raison je propose de discuter à l'occasion de notre assemblée prochaine à Montréal la possibilité de microfilmer les archives des observatoires et de concentrer le matériel international dans un archive central." Ce point est porté à l'ordre du jour des réunions de la Commission 5 à l'Assemblée Générale de Montréal.

On notera les deux publications suivantes :

- Union catalogue of printed books of the XV and XVI centuries in astronomical European Observatories, compiled by G. Grassi, 1977, Oss. Astron. Roma, Contr. Scientif. Série III, n¹55.

- J.A. Bennett : Catalogue of the archives and manuscripts of the Royal Astronomical Society (Mem. R. Astron. Soc., 1978, 85, 1-90).

2. Observatoires astronomiques et astronomes.

L'annuaire jadis publié sous les auspices de l'UAI (1959) a vieilli sans appel (Martynov). Le fichier tenu par M. Velghe pourrait-il être régulièrement mis à jour et disponible sur bande magnétique?

3. Nomenclature des objets stellaires, galactiques et extragalactiques.

Une discussion sur ce thème devrait avoir lieu à Montréal. On notera le besoin d'établir un système uniforme de désignation des catalogues d'observations; de désigner de façon non équivoque les différents types d'objets astronomiques; d'assurer l'adoption par les journaux scientifiques de règles permettant l'identification correcte des objets apparaissant dans les publications (C. Jaschek; M.C. Lortet).

\section{RELATIONS AVEC D'AUTRES ORGANISATIONS.}

1. ICSU $A B$ : Le Président de la Commission 5 représente, ex officio, l'UAI à 1'ICSU AB. En 1976, W.D. Heintz a représenté l'UAI à la réunion de Philadelphie; en 1977, J.-C. Pecker a représenté l'UAI à York; en 1978, L.Schmadel a représenté l'UAI à Toulon. Parmi les décisions importantes figure la mise sur pied de six groupes de travail définis par des tâches précises, à savoir : "input cooperation; output-repacking; technical resource sharing; research and development activities; user education and training; community concerns. On notera la publication en 
1978-79 de I'"Aggregate list" qui contient environ 30000 titres de journaux scientifiques et techniques, abréviations et codes ISSN et CODEN.

2. POGSI : The Policy Group on Scientific Information, created by the ICSU, under the chairmanship of Prof. J.Sahade, has produced an evaluative study of Unisist for the period 1971-1976. POGSI intends to continue to play its role of studying the problems of scientific information, especially by establishing a proper link between the scientific community, represented in ICSU, and the important groups dealing with scientific information at the intergovernmental level, such as UNESCO (with its General Programme of Information, and Unisist) or UNO.

3. Madame G. Grassi nous informe régulièrement des activités de la Sous-Section des Bibliothèques Astronomiques et Géophysiques de l'IFLA.

4. CODATA; FAGS : voir ci-dessus, paragraphe II.

VI. ACTIVITES FUTURES DE LA COMMISSION 5.

Une enquête auprès des membres et membres consultants de la Commission, outre certains points mentionnés ci-dessus, a fait ressortir l'intérêt des questions suivantes : computerization in indexing, and interrogation of automatized data bank; use of tapes, cassettes, disks for archiving astronomical data; cooperation with scientific groups, such as COSPAR, to produce series of popular books.

$$
\text { J.-C. PECKER }
$$

Président de la Commission. 